University of Nebraska - Lincoln

DigitalCommons@University of Nebraska - Lincoln

$12-2013$

\title{
RECENT INCOME TRENDS FOR TOP EXECUTIVES: EVIDENCE FROM TAX RETURN DATA
}

Seth H. Giertz

University of Nebraska-Lincoln, sgiertz2@unl.edu

Jacob A. Mortenson

Georgetown University,.jm849@georgetown.edu

Follow this and additional works at: https://digitalcommons.unl.edu/econfacpub

Giertz, Seth H. and Mortenson, Jacob A., "RECENT INCOME TRENDS FOR TOP EXECUTIVES: EVIDENCE FROM TAX RETURN DATA" (2013). Economics Department Faculty Publications. 86.

https://digitalcommons.unl.edu/econfacpub/86

This Article is brought to you for free and open access by the Economics Department at DigitalCommons@University of Nebraska - Lincoln. It has been accepted for inclusion in Economics Department Faculty Publications by an authorized administrator of DigitalCommons@University of Nebraska - Lincoln. 


\title{
RECENT INCOME TRENDS FOR TOP EXECUTIVES: EVIDENCE FROM TAX RETURN DATA
}

\author{
Seth H. Giertz and Jacob A. Mortenson
}

We examine income trends for top executives, focusing on the years 2000 to 2010, with special emphasis on the period surrounding the Great Recession. First, we merge Execucomp executive compensation records with IRS tax records. We compare incomes from our Execucomp sample to top incomes reported by Piketty and Saez (2003). We disaggregate executive income trends by industry, showing which industries are driving the divergence in top executive incomes. We compare our results to findings from Bakija, Cole, and Heim (2010) and Kaplan and Rauh (2010), who examine trends in top incomes for broad occupation and industry categories for years prior to the Great Recession. We also decompose these income trends by income source to see which components are driving the observed changes. We find that stock options are by far the most volatile component of executive pay. Options are the key driver of both short-term swings and longer-term trends in top executive pay. However, stock awards are also a large and growing component. We find much greater variation in income across years than across industries. Executive incomes are most volatile at the very top of income distribution. In general, trends for top executives in finance and non-finance industries are quite similar; however; for those above the $99.9^{\text {th }}$ percentile of the income distribution, the decline in income from 2006 to 2009 was much more pronounced for executives in finance.

Keywords: executive compensation, top incomes

JEL Codes: H2, J3

\section{INTRODUCTION}

ver the past several decades, income has become much more heavily concentrated at the very top of the income distribution. While the top decile has fared better than rest of the distribution, the most dramatic changes have involved the extreme right tail of the income distribution - i.e., those in the top tenths of the top 1 percent. The

\footnotetext{
Seth H. Giertz: Department of Economics, University of Nebraska-Lincoln, Lincoln, NE, USA (giertz@unl.edu) Jacob A. Mortenson: Department of Economics, Georgetown University, Washington, DC, USA, and Joint Committee on Taxation, Washington, DC, USA (jm849@georgetown.edu)
} 
recent financial crisis has heightened concerns that the incentives of executives are misaligned with the interests of shareholders, or at least the interests of society at large. Additionally, there is a perception that while the top of the distribution has enjoyed tremendous income gains, incomes at the median (and more generally for the bulk of Americans) have stagnated. ${ }^{1}$

Incomes of high-level executives are frequently used as examples of rising inequality. In attempts to better align the interests of managers with those of shareholders, executives are often rewarded (or punished) based on the performance of the firm; however, to a great extent, firm performance is driven by forces outside any individual's control. ${ }^{2}$ A growing perception is that executive pay is often excessive, not merit-based, and that incentives for managers and shareholders are not properly aligned. Some argue that the often super-high incomes of executives are to a large extent the product of malfeasance or gaming of the system (Bebchuk, Fried, and Walker, 2002; Kuhnen and Zwiebel, 2009). Others argue that executive incomes at large firms (particularly financial institutions) are artificially high due to implicit government guarantees that generally protect bondholders against losses and in so doing, lower borrowing costs and encourage excessive risk taking (Stern and Feldman, 2004).

Top executives are highly concentrated within the very top of the income distribution. However, they likely remain a small minority even among the very top income groups. Based on Execucomp data, Kaplan and Rauh (2010) report that Execucomp executives comprise roughly 3 percent of the top 0.1 percent of the income distribution. Including imputations for executives in non-Execucomp firms only modestly raises these estimates. ${ }^{3}$

Previous studies have used executive compensation data (usually required as part of SEC filings) to examine trends in executive or CEO compensation (Eissa and Giertz, 2006; Goolsbee, 2000; Hall and Liebman, 2000; Frydman and Saks, 2010). Other studies have used tax data to examine top incomes, but these studies usually cannot separately identify executives from others with high incomes. Bakija, Cole, and Heim (2010) is an exception in that they impute occupations for tax filers, including executives. However, no study to our knowledge has merged executive compensation data directly with U.S. tax returns.

In this paper, we examine income trends for top executives, focusing on the years 2000 to 2010, with special emphasis on the period surrounding the Great Recession.

1 The extent to which this is the case depends heavily on how income is measured. Meyer and Sullivan (2012), Burkhauser, Larrimore, and Simon (2012), and Saez (2013) provide examples.

2 For example, Kahneman (2011, p. 205) notes that, "A very generous estimate of the correlation [coefficient] between the success of the firm and the quality of its CEO might be as high as $0.30[$.$] "$

3 Using tax data, Bakija, Cole, and Heim (2010) report that non-financial executives, managers, and supervisors plus financial professionals make up roughly 60 percent of the top 0.1 percent of the income distribution. This is a much broader sample than the Execucomp, and includes many non-executives, executives who are not present in SEC filing (because they are not among the highest paid at their firms), and executives at non-Execucomp firms. 
The definition of income used is a product of the information available in the tax and Execucomp datasets. Each of the two datasets has its strengths and weaknesses; however, neither allows for the calculation of Haig-Simons income. For a given period, HaigSimons income equals consumption plus the change in wealth occurring in that period. Income measures based on tax data deviate from the Haig-Simons standard in that they usually cannot account for tax exclusions and tax-deferred income - for example from pensions or retirement savings accounts and from some forms of capital income. ${ }^{4}$ Tax evasion also causes measures based on tax data to deviate from Haig-Simons income. Some forms of deferred income can be imputed from executive compensation records; however, these data also do not capture all income and, as with tax data, some income sources are not reported in the period in which the income is earned. Our income measures are based on others used in the tax literature. In the following section, we describe the sources of income used in this paper, and highlight the timing of income reporting. This provides an indication of which sources are likely to yield deviations from the Haig-Simons standard.

In the next section, we provide background on our datasets and how they are merged. In Section III, we compare incomes from our Execucomp sample to top incomes reported by Piketty and Saez (2003). We decompose these income trends by income source to see which components are driving changes. We find that stock options are by far the most volatile component of executive pay. Options are the key driver in both short-term swings and longer-term trends in top executive pay. However, stock awards are also a large and growing component - although until recently they were not separately reported. We disaggregate executive income trends by industry, showing which industries are driving the divergence in top executive incomes. We compare our results to the findings from Bakija, Cole, and Heim (2010) and Kaplan and Rauh (2010), who examine trends in top incomes for broad occupation and industry categories for years prior to the Great Recession. We find greater variation in income across years than across industries. Executive incomes are most volatile at the very top of the income distribution. In general, trends for top executives in finance and non-finance industries are quite similar; although for those above the $99.9^{\text {th }}$ percentile of the income distribution, the decline in income from 2006 to 2009 was much more pronounced for executives in finance.

\section{CONSTRUCTING A DATASET: MATCHING EXECUTIVES TO TAX RETURNS}

We link individual tax returns from the Internal Revenue Service's Compliance Data Warehouse (CDW) with Execucomp compensation records for CEOs plus the next four highest paid executives (based on salary and bonus income). ${ }^{5}$ By exactly match-

\footnotetext{
4 Tax-deferred income may eventually show up on tax returns. However, a Haig-Simons income calculation would require information on income when it accrues (as opposed to when it is realized).

5 For the most recent years, compensation is reported for the CEO, CFO, and the next three highest paid executives. In most instances, this amounts to the firm's five highest-paid executives.
} 
ing executives to their tax returns, we are able to examine the tax information for this important and primarily very high-income group. Conversely, we are able to examine income sources for these tax filers that are not reported to the IRS.

The Execucomp data contain information on 38,500 unique executives spanning the years 1992 to 2010. These data are compiled by Standard and Poor's from proxy statements and 10-K forms (filed with the Securities and Exchange Commission) and are part of S\&P's Compustat database. Included in the dataset are corporations in the Standard and Poor's S\&P 1500 Index (i.e., corporations in the S\&P 500, S\&P Mid Cap 400, and S\&P Small Cap 600). The data are primarily a subset of U.S. taxpayers near the very top of the income distribution. The compensation information includes salaries, option awards, option values, long-term incentive plan payments (LTIP), bonuses, stock grants, and many other forms of taxable and non-taxable income. The company information includes total assets, market capitalization, earnings, total employment, and other financial information.

Annual Statistics of Income (SOI) Public Use Files (PUFs) have been the most important source for tracking trends in top incomes for the United States. However, the PUFs remove information that could be used to identify individual taxpayers (or to link taxpayers across years). A panel of tax returns was made public for years 1979 to 1990 , but the sample sizes are too small to effectively examine trends at the very top of the income distribution. In terms of confidential tax data, the SOI maintains a stratified random sample of tax returns that heavily oversample top incomes. While this dataset includes tax returns for executives at the very top of the income distribution, it does not sample many with moderately high (as opposed to very high) income.

The CDW data, on the other hand, include tax returns for the universe of U.S. tax filers for the years 1996 to 2011 and are only available to a handful of groups within the U.S. Department of the Treasury (Treasury) and Joint Committee on Taxation. Major sources of income (e.g., taxable income, deductions, credits), commonly used forms (e.g., Form 1040, Form W-2, and various schedules), and other information are available for every return.

Even with the universe of tax returns, matching tax information to executives is complex. The Execucomp does not include unique Individual Taxpayer Identification Numbers (ITINs), which would make the match straightforward, ${ }^{6}$ and no single shared and unique identifier is included in both datasets. However, by matching based on an array of variables available in both datasets, we can produce exact matches for most executives. Because W-2 forms (submitted by employers) are incorporated into the CDW beginning in 2000, we have several pieces of identifying information in both datasets. ${ }^{7}$ These include the company EIN and the last name, first name, and middle

${ }^{6}$ For most taxpayers, Social Security numbers double as taxpayers' ITINs. Taxpayer Identification Numbers (TINs) refer to a category of identifiers (of which ITIN is one), which are not necessarily unique taxpayer identifiers. The Employer Identification Number (EIN) is an example of a TIN that is not unique to each taxpayer.

7 We focus on the period beginning with 2000 because our match rate is much worse pre-2000, when Form $\mathrm{W}-2$ is not available. 
initial of the individual. Year of birth and sex from the Social Security Administration's Data Master File (DM-1) are also used. After matching TINs to the Execucomp, we retrieve tax information from the Statistics of Income (SOI) Databank and Form 1040 from the CDW.

For the years 2000 to 2010, our core sample contains 214,500 tax observations, 120,500 Execucomp observations, and 245,500 total observations (i.e., observations that contain tax or Execucomp information). ${ }^{8}$ We match 89,500 of the 120,500 observations (a 74 percent matching rate). ${ }^{9}$ While individuals may fall out or re-enter the Execucomp sample over time (e.g., by leaving a firm or dropping in their firm's compensation rankings), the tax data are available for every year in which the individual filed a tax return or had certain information returns filed on his behalf.

Tables 1 and 2 summarize the company and individual data from both data sources. We define executive income (based on Execucomp data) as the sum of the value of salaries, bonuses, options exercised, long-term incentive plan payments (LTIP), and

\section{Table 1}

IRS and Execucomp Income (2000\$,Thousands): Sample Size and Means for the Matched Sample (Exact Matches Between Executives and IRS Records)

\begin{tabular}{lccc}
\hline Year & Observations & Taxable Income & Executive Compensation \\
\hline 2000 & 8,636 & 1,904 & 2,685 \\
2001 & 8,637 & 1,432 & 1,878 \\
2002 & 8,685 & 1,297 & 1,523 \\
2003 & 8,789 & 1,452 & 1,777 \\
2004 & 8,092 & 1,948 & 2,257 \\
2005 & 6,983 & 2,279 & 2,667 \\
2006 & 7,411 & 2,367 & 2,751 \\
2007 & 8,037 & 2,449 & 2,709 \\
2008 & 7,783 & 1,904 & 2,056 \\
2009 & 7,404 & 1,683 & 1,805 \\
2010 & 6,971 & 2,091 & 2,360 \\
\hline
\end{tabular}

Source: Authors' calculations based on IRS CDW and Execucomp data

\footnotetext{
8 Note two sample restrictions. First, tax observations after an individual's year of death are dropped. Second, the record for executives with multiple records in a given year - for example, if the person held positions with multiple firms during the year - the record with the largest income is kept and the others are dropped.

9 Appendix A provides more details on our matching strategy.
} 
Table 2

Average Annual Firm and Individual Economic Statistics (Matched Sample)

\begin{tabular}{|c|c|c|c|}
\hline \multicolumn{4}{|c|}{ Execucomp Firms (2000\$, Millions) } \\
\hline & Mean & $\begin{array}{l}\text { Standard } \\
\text { Deviation }\end{array}$ & Total \\
\hline Total assets & 12,900 & 73,200 & $24,245,000$ \\
\hline Market value & 6,220 & 20,700 & $11,225,000$ \\
\hline \multicolumn{4}{|c|}{ Execucomp Individuals (2000\$, Thousands) } \\
\hline & Mean & $\begin{array}{l}\text { Standard } \\
\text { Deviation }\end{array}$ & Total \\
\hline Salary & 369 & 248 & $3,007,000$ \\
\hline Bonus & 266 & 992 & $24,100,000$ \\
\hline Options exercised & 812 & 1,049 & $77,200,000$ \\
\hline Non-equity incentive plan compensation & 363 & 5,219 & $14,000,000$ \\
\hline Stock awards & 617 & 1,563 & $22,700,000$ \\
\hline Long-term incentive plan compensation & 89 & 668 & $4,580,000$ \\
\hline Restricted stock grants & 255 & 1,244 & $13,200,000$ \\
\hline Execucomp income & 2,220 & 6,231 & $17,710,000$ \\
\hline
\end{tabular}

IRS Measures (2000\$, Thousands)

\begin{tabular}{lrrr}
\hline & & Standard & \\
& Mean & Deviation & \multicolumn{1}{c}{ Total } \\
\hline Wages & 1,993 & 4,612 & $16,164,000$ \\
Taxable interest & 71 & 1,242 & 576,000 \\
Taxable dividends & 155 & 2,177 & $1,254,000$ \\
Schedule C income & 13 & 327 & 102,000 \\
Schedule D income & 465 & 4,658 & 3,771 \\
Adjusted gross income & 2,654 & 7,816 & $21,519,000$ \\
Deductions & 339 & 1,696 & $2,752,000$ \\
Taxable income & 1,849 & 5,149 & $14,996,000$ \\
\hline
\end{tabular}

Source: Authors' calculations based on IRS CDW and Execucomp data

restricted stock grants for the years 2000 through 2005. Due to changes in SEC reporting requirements, LTIP and restricted stock grants are reported differently beginning in 2006. We follow the approach of Frydman and Jenter (2010) by replacing these two items with non-equity incentive plan compensation and the fair value of stock awards after 2005. Based on the tax data, we define taxable income as adjusted gross income (AGI) reported on Form 1040 less deductions (the larger of itemized deductions or the 
standard deduction) and capital gains (i.e., Schedule D profit or loss). Adjusted gross income is the difference between total income - again, as defined on Form 1040 — and adjustments (i.e., above-the-line deductions). Note that capital gains are often examined separately when using tax data, in part because they are only observed when realized, as opposed to when they accrue. Capital gains realizations are generally more volatile and lumpy than other income sources, and often the timing of realizations is heavily influenced by tax changes and the performance of the broader stock market.

In most cases, these various sources of executive income are subject to taxation as ordinary income. Firms generally may deduct these expenses in the same period in which the executive is required to report them for tax purposes; however, since 1993, the deductibility of most "non-performance-based" compensation is capped at $\$ 1$ million per employee.

The time at which income sources are subject to taxation varies. For example, income from salaries and bonuses is taxed in the period in which is it earned. Restricted stock grants, non-equity incentive plans, and other long-term incentive plans are also generally taxed as ordinary income, but usually not in the period that they are issued (or in which the incentive is put in place). In most cases, these income sources are taxed when they vest. ${ }^{10}$ Vesting occurs after a set period of time or after certain performance measures are reached. Taxing at the time of vesting is similar to the treatment of salaries and bonuses, since the executive has not officially earned the income prior to vesting.

Traditionally, non-qualified options represent the vast majority of stock options for executives (Hall and Liebman, 2000). The value of non-qualified options is generally taxable when the option is exercised, as opposed to when it is issued or vested. Because these options are generally not tradable, they are deemed to have no "readily ascertainable market value" when issued; otherwise, they would be taxed at the time of issue. The difference between the market price and the exercise price is reported as salary income on Form W-2 and is subject to income and payroll taxes. ${ }^{11}$

\section{GENERAL INCOME TRENDS AND DECOMPOSING SOURCES}

\section{A. Background on Top Incomes}

In their heavily cited work, Piketty and Saez (2003) document a divergence in income shares received by those at the top of the income distribution from those in the rest of the distribution. Piketty and Saez show that top income shares fell abruptly during

\footnotetext{
${ }^{10}$ Stock awards that are immediately vested are less common and are taxed in the period in which they are issued.

${ }^{11}$ By contrast, qualified stock options - a very small component of overall stock options - are not taxed when issued or exercised, but when the recipient sells the stock purchased via the options. At this point, the realized income is generally treated as long-term capital gains. Qualified stock options are limited to a maximum of $\$ 100,000$ per employee and, in contrast to non-qualified options, firms may not deduct their value for corporate tax purposes. Bickley (2012) provides more details.
} 
World War II and held relatively steady for the next few decades. Incomes at the very top of the distribution are consistently more volatile, experiencing sharper drops in downturns and sharper upticks during expansions. However, over longer time frames, clear patterns emerge. Beginning in the 1970s, the divergence of top incomes became a dominant phenomenon (Figure 1). ${ }^{12}$ Excluding capital gains, the share of total reported income accruing to the top 10 percent rose from 32 percent in 1973 to over 46 percent by 2010 . This divergence, however, is primarily driven by the top 1 percent. Whereas the share received by the top 1 percent rose by 124 percent over this period, the share received by those in the $95^{\text {th }}$ to $99^{\text {th }}$ percentiles rose by 27 percent. Those in the $90^{\text {th }}$ to $95^{\text {th }}$ percentiles saw their share increase by only 12 percent. $^{13}$

An important caveat to the analysis by Piketty and Saez (2003) and the analysis presented later in this paper is that income shares are measured based on repeated crosssections. Repeated cross-sections focus on segments of the annual income distribution, without regard to the position of these taxpayers in previous (or subsequent) years. Put another way, this type of analysis does not follow the same people over time. The composition of individuals within an income group may vary greatly from year to year. The question of income volatility or mobility is not our focus, but is an important issue that may influence normative implications from this type of analysis. ${ }^{14}$

There is no consensus as to the primary factors driving changes at the top of the income distribution. However, very-high top marginal tax rates coincided with the sharp compression during World War II. In fact, in 1942 President Roosevelt called for a 100 percent tax rate (for the top tax bracket) saying "no American citizen ought to have a net income, after he has paid his taxes, of more than $\$ 25,000$ a year ..." (Bank, Stark, and Thorndike, 2008, p. 97). Shortly thereafter, the top federal tax rate reached 94 percent (for income over $\$ 200,000$ ). Top rates stayed above 90 percent until the 1960s when the top statutory rate was lowered to 70 percent. By 1988, after full enactment of the Tax Reform Act of 1986, the statutory rate for top incomes fell all the way to 28 percent. Thus, the shift towards pre-1930s income concentration loosely coincided with the lowering of top tax rates, especially since the 1980s.

${ }^{12}$ While the divergence at the top of the income distribution is well established, the methodology employed can affect the magnitude of the changes. For example, using restricted (and not top coded) Current Population Survey data, Burkhauser, Larrimore, and Simon (2012) and Burkhauser et al. (2012) show that adjusting for factors such as changes in family structure, income sharing within the family, the value of government transfers, and tax exclusions (such as for employer-provided health insurance) generates different results, relative to using the tax unit as the unit for analysis and not accounting for information not reported on tax returns. These methodological factors have major implications when examining income growth for households in the middle and at the bottom of the income distribution - showing substantial gains accruing to the bottom half of the distribution over the past few decades, as opposed to stagnation or decline. Under their alternative approach, the degree of divergence in the overall income distribution is also lessened.

${ }^{13}$ Unless otherwise noted, income shares from the overall distribution of taxpayers are from Piketty and Saez (2003).

${ }^{14}$ Corak (2013), Kopczuk, Saez, and Song (2010), Auten and Gee (2009) and Dahl, DeLeire, and Schwabish (2008) examine the mobility of top incomes over time. 


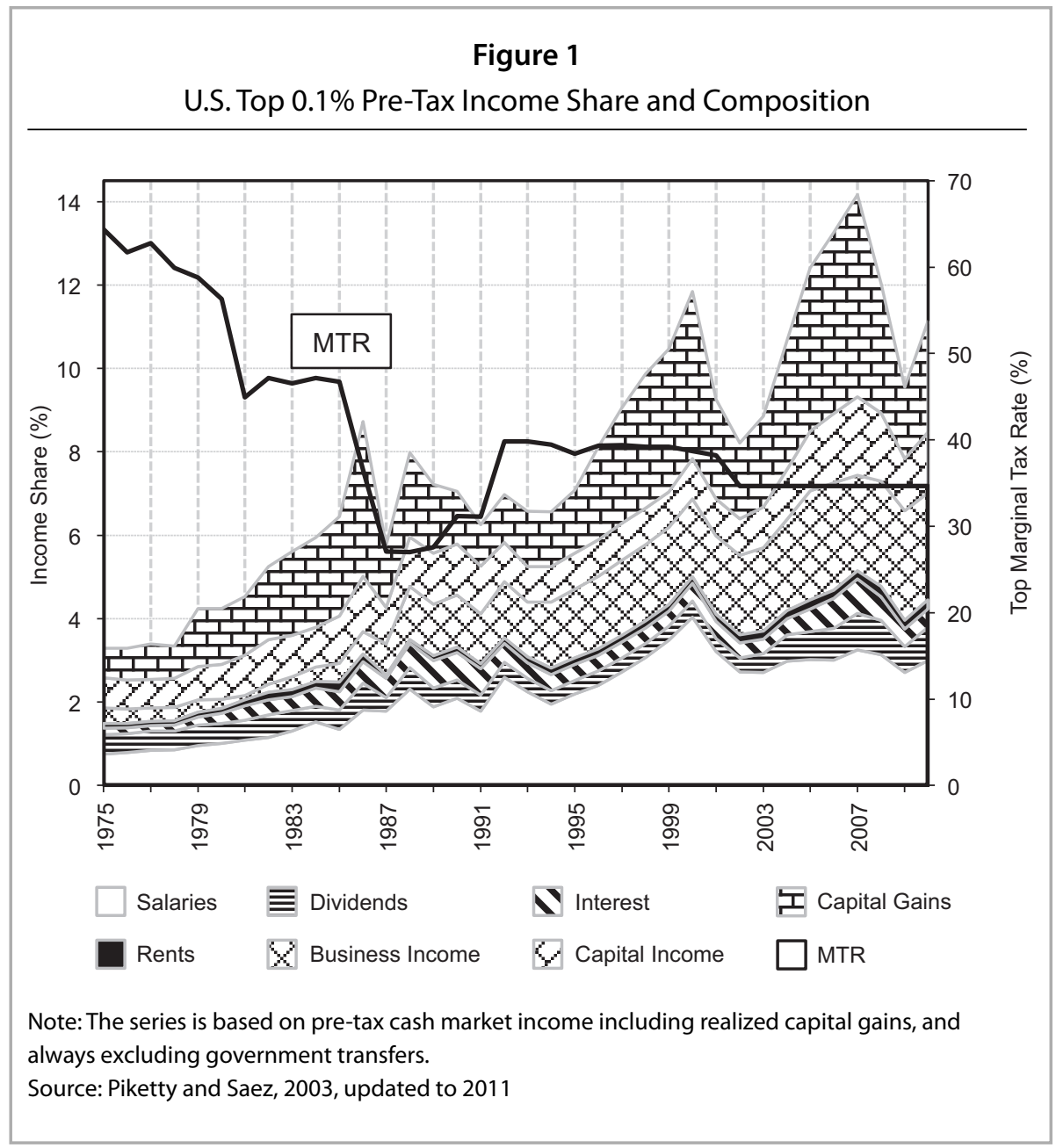

A series of international studies of top incomes edited by Atkinson and Piketty (2007) do not rule out taxes as playing a major rule. However, the studies do not definitively support such a proposition either, suggesting that if taxes are the key factor, their impact may accrue over a number of years. Bakija, Cole, and Heim (2010) present more than a half-dozen hypotheses that attempt to explain the divergence at the top of the income distribution. One such hypothesis argues that executive compensation is a driving factor. Some evidence suggests that the rapid rise in executive compensation may be consistent with efficient business practices (Hall and Murphy, 2003; Gabaix and Landier, 2008; Gabaix, Landier, and Sauvagnat, 2013; Kaplan and Rauh, 2013; Mankiw, 2013), while others argue that principal-agent problems have allowed executives to take advantage of 
shareholders by awarding themselves lavish compensation packages (Bebchuk, Fried, and Walker, 2002; Kuhnen and Zwiebel, 2009), or that recent income divergence has been driven by economic rents (Bivens and Mishel, 2013). These competing views are also discussed by Frydman and Saks (2010) in their examination of long-run trends in CEO compensation.

Kaplan and Rauh (2010) look at the role of executives in the divergence of incomes at the top of the income distribution. They further examine trends for executives in the finance sector as compared to those in other sectors. Using data from 1994 and 2004, they report that average realized income for executives in the finance sector and nonfinance sectors both increased by similar rates - cumulatively, an over 200 percent increase - and average income for those in the finance sector was about 50 percent higher than those in non-financial sectors in both years. ${ }^{15}$ The presence of both groups at the very top of the income distribution increased, but the increase was somewhat greater for executives in non-financial sectors. Kaplan and Rauh (2010) further measure the contribution of other high-paid groups to the growth in top incomes. These include non-executives in the finance industry, as well as lawyers, professional athletes, and celebrities. They conclude that "powerful CEOs or poor corporate governance cannot possibly be more than a small part of the picture of increasing income inequality, even at the very upper end of the distribution ... [although] this does not rule out the possibility that poor corporate governance affects CEO pay" (Kaplan and Rauh, 2010, p. 44).

Many studies have used executive compensation data to examine income trends and behavioral responses to taxation, including Eissa and Giertz (2006), Goolsbee (2000), Hall and Liebman $(1998,2000)$, and Frydman and Jenter (2010). ${ }^{16}$ While these studies include sources of income not reported on tax returns, they also omit important tax information. For example, several use executive compensation data to measure behavioral responses to changes in marginal tax rates. They generally find that the earnings of executives are less responsive to changes in tax rates than are other high-income groups studied using tax data; however, executive compensation may be an imperfect proxy for taxable income. Several items, such as itemized deductions or income from outside the executive's firm, are not observed in executive compensation data. In general, capital gains realizations are also not observed. If these are important margins by which high-income taxpayers respond to tax changes, estimated elasticities based solely on executive compensation data may substantially underestimate overall behavioral responses to taxation.

In the remainder of this section, we examine recent income trends for executives, a group heavily represented at the top of the income distribution. We compare our results to trends for high-income groups more generally, as reported by Piketty and Saez (2003) (updated through 2011) and to trends by industry and occupation as reported by Bakija,

\footnotetext{
${ }^{15}$ The overall growth rate in both sectors is sensitive to their choice of income measure. Income growth for both sectors is much lower using an ex ante measure of income. However, under both measures, the growth rate is similar for executives in both sectors.

${ }^{16}$ Frydman and Jenter (2010) provide a review of this literature as it pertains to CEOs.
} 
Cole, and Heim (2010), who also examine income trends using tax data through 2005; the latter study includes industry and occupation information inferred from W-2 forms and the occupation field on the Form 1040. Among those at the top of the income distribution, they report different income trends for several occupations, including executives. This work also relates closely to that of Kaplan and Rauh (2010).

\section{B. The Changing Composition of Executive Compensation and Top Incomes}

Figure 1 presents trends in mean pre-tax income shares over time and decomposed by source. This figure is based on public-use IRS data compiled by Piketty and Saez (2003). Instead of presenting a figure for overall tax returns, we focus on the top 0.1 of 1 percent of returns. As shown later in this section, this group includes a large share of top executives - in fact more than 30 percent of our matched sample — and accounts for 80 percent of taxable income and Execucomp income in our matched sample. Figure 1 focuses on the very top of the income distribution; however, the overall income distribution is an important component of the measure because income is presented as a share of income for the population of taxpayers. While the focus of this paper is primarily on years 2000 to 2010, Figure 1 extends to 1975 for perspective.

The long-term trend for this top income group is strongly positive, as discussed earlier for top incomes more generally. The share of income accruing to the top 0.1 percent in Figure 1 averages 6.7 percent and ranges from 2.6 percent in 1975 to 12.3 percent in 2007. With the stacked diagram, one can see the growth of each income source over this period and the relative size of the source compared to the total. For example, in 2007, when this top group's income accounted for 12.3 percent of income reported by all taxpayers, over 34 percent of this share can be attributed to capital gains (i.e., 4.8 percentage points) and 23 percent can be attributed to salaries (i.e., 3.3 percentage points).

The income share for the top 0.1 percent is extremely volatile. For example, the income share rose by over 67 percent ( 7.3 percent to 12.3 percent) from 2002 to 2007 and then fell by more than 32 percent (12.3 percent to 8.3 percent) from 2007 to 2009 . These wide fluctuations are driven predominantly by net capital income. ${ }^{17}$ Capital income is both a large share of income in Figure 1 - on average, comprising an over 27 percent share for this group - and very volatile. Salaries and business income are also major income sources for this group. Combined, these two sources account for more than 43 percent of the income of this group on average. Salary income has grown roughly on par with overall income for this group. Salary income was more volatile after the recession of the early 2000s than during the Great Recession. Business income grew much more rapidly over this period than income from other major income sources. However, a substantial portion of this growth likely represents the shifting of income

\footnotetext{
${ }^{17}$ Capital gains are closely tied to the performance of the stock market and are only reported when realized - i.e., when the taxpayer chooses to sell the asset. A presentation based on capital gains accrual would likely look very different and probably be less volatile.
} 
from Subchapter C to Subchapter S corporations following the Tax Reform Act of 1986 (Slemrod, 1996; Carroll and Joulfaian, 1997; Saez, Slemrod, and Giertz, 2012).

Figure 2 displays trends in the mean components of Execucomp executive income for the years 1992 to 2010. Executive compensation over these two decades is characterized by large peaks and valleys. As in Figure 1, incomes are especially volatile in the years surrounding the last two recessions. Also, despite a 50 percent decline between 2006 and 2009, mean executive compensation increased 124 percent over the 19-year period.

Frydman and Jenter (2010) document the growth in pay for CEOs and other top executives since the 1930s. The trends we report in mean compensation from the last decade (in Figure 2) are consistent with their trends in median compensation from the 1990 s, in which executive compensation continues a rapid growth trend that began in the mid 1970s. Our data show that from 2000 to 2002, mean executive compensation

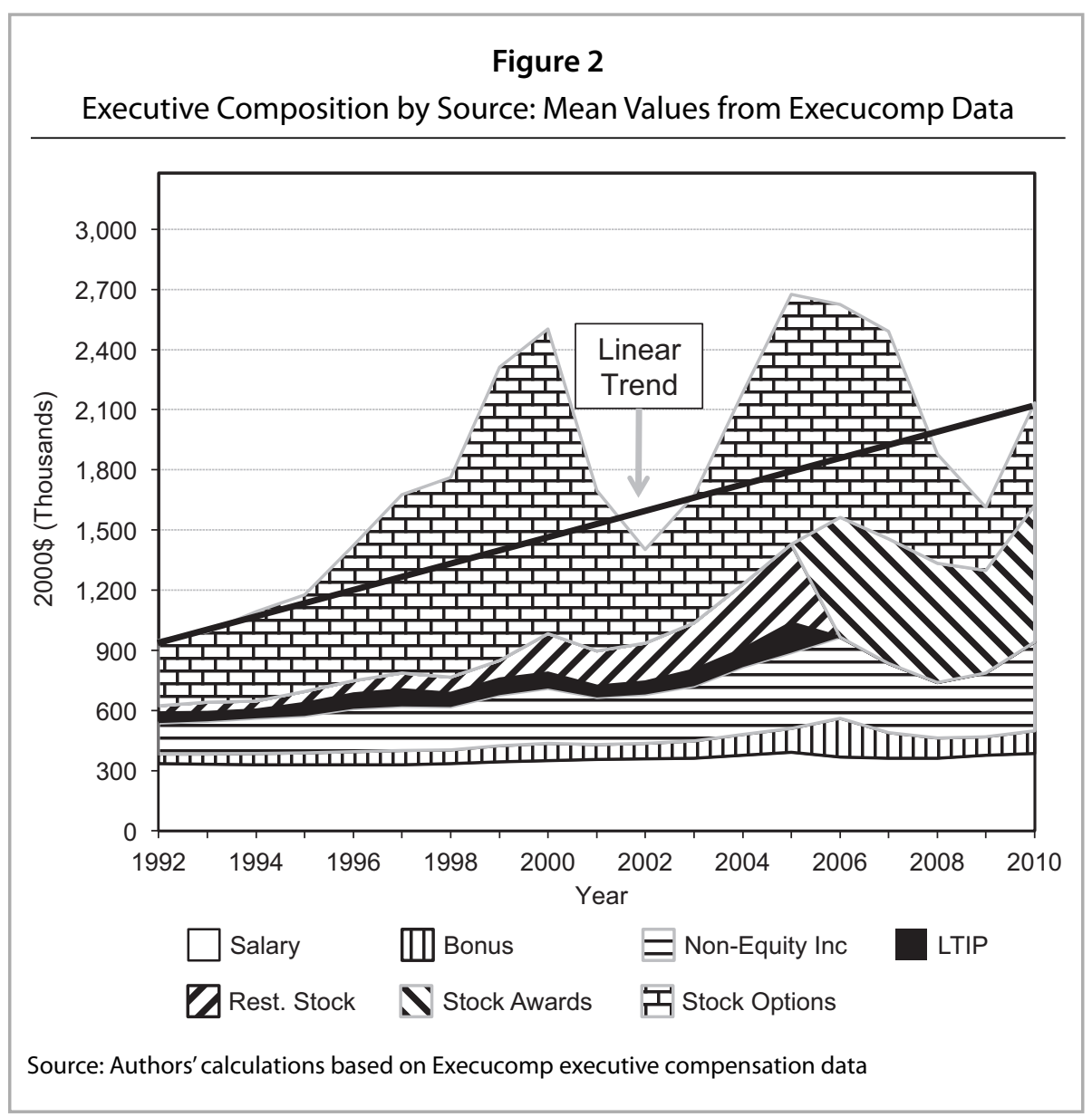


mirrored the business cycle, plummeting 43.9 percent, before rising 130 percent from 2002 to 2006. Despite an upward trend since 2009, mean executive compensation in 2010 is down 34 percent from its 2006 peak.

Salary income shows the least volatility and on average grows more slowly than overall compensation. As a share of overall executive compensation, salary income falls by roughly half over the last two decades - from a 35 percent share in 1992 to an 18 percent share in 2010. Salaries increase by 4.4 percent from 1992 to the 2000 peak. From 2000 to 2010, they increase another 10.3 percent.

Realized income from stock options is the major driver underlying the overall trends. Because this source is not measured when vested or issued, it likely reflects earnings from earlier periods, as well as gains or losses driven by changes in the price of the underlying stock after vesting. Not surprisingly, the value of stock options swings wildly with the stock market. At the beginning of the period, this source represents 35 percent of total executive compensation. It peaks as a share of total executive compensation at 63 percent in 1999 and reaches a nadir, at 19 percent, in 2009. Despite rising in absolute terms by 363 percent from 1992 to 2000 and by 127 percent from 2002 to 2006, the value of stock options was up just 55.9 percent on net from 1992 to 2010. From 2000 to 2010 , their value fell by 33.7 percent, on net.

The decline of stock options at the end of the last decade roughly coincides with a reporting requirement change adopted by the SEC in 2006. The changes were intended to provide a more complete and transparent picture of executives' compensation, and in particular were meant to address concerns over the backdating of options (Borges, 2012). These changes, however, complicate the construction of a consistent measure of executive compensation across years, as several Execucomp variables were dropped or amended, while others were added, beginning in 2006. Among the changes, compensation that had been reported as long-term incentive plan compensation and restricted stock grants are now grouped in other categories. Post 2005, our definition of executive compensation includes non-equity incentive plan compensation and the value of (vested) stock awards in their place. ${ }^{18}$

Non-equity incentive plan payments are primarily cash incentives tied to a firm's performance. Prior to 2006 they were mostly a subset of bonuses, and partly a subset of long-term incentive plan compensation. Post 2006, non-equity incentive plan compensation accounts for 76 percent of total bonuses (roughly the sum of "bonus" and non-equity incentive plan compensation) on average per year. We impute non-equity incentive plan compensation going back to 2000 using this ratio. In terms of volatility, total bonuses are closer to stock options than salaries. Mean bonuses roughly doubled from 2001 to 2006, rising from $\$ 310,000$ on average to $\$ 597,000$ in 2006. Early evidence suggests that the Great Recession may be merely a hiccup in this trend, as mean bonuses fell to $\$ 379,000$ on average in 2008 before recovering to $\$ 555,000$ on average in 2010 .

\footnotetext{
${ }^{18}$ Borges (2012) provides a discussion of the reporting requirement changes.
} 
Stock awards represent the value of equity awards that are not options and that vest within the year. This measure is a more relevant component of annual compensation than restricted stock grants, if one wants a measure analogous to annual taxable income. Stock awards are somewhat less volatile than bonuses or options, but are a large component of total compensation. Between 2008 and 2010 stock awards were the largest single component of mean executive compensation, with an average value of $\$ 680,000$ in 2010. Average stock awards between 2006 and $2010(\$ 600,000)$ were roughly twice as large as the average restricted stock grants between 2000 and $2005(\$ 250,000)$. It is not known whether this represents a shift from options to other stock awards compensation (options declined during the Great Recession and have not recovered) or a more direct consequence of the change in disclosure rules.

\section{Comparing Executives with Similarly Situated Taxpayers}

Not all executives have extraordinarily high incomes. Even when looking at only the five highest paid executives at publicly traded firms, those at the very bottom of this distribution have taxable incomes (net of capital gains) that are negative, on average. Moving to the $5^{\text {th }}$ percentile, average incomes from 2000 to 2010 were $\$ 144,000$ - well within the top 5 percent of the overall income distribution, but still rather moderate. However, the vast majority of executives in the Execucomp (i.e., generally CEOs plus the next four highest paid executive at firms in the S\&P 1500 Index) have incomes that are well above the top 1 percent of the overall income distribution.

Figure 3 shows that taxable income for the $5^{\text {th }}$ percentile of our matched sample of executives is generally higher than the $95^{\text {th }}$ percentile of the overall distribution of tax filers. The $99^{\text {th }}$ percentile of the overall distribution falls below that of the $20^{\text {th }}$ percentile of executives ( $\$ 309,000$ average). ${ }^{19}$ Figure 4 reveals that taxable income at the $99.9^{\text {th }}$ percentile (i.e., the top 0.1 of the top 1 percent) is quite similar to that for the $70^{\text {th }}$ percentile (an average of $\$ 1.5$ million) of the distribution of matched executives. Income for the $99.99^{\text {th }}$ percentile of taxpayers is similar to those at the $90^{\text {th }}$ percentile (\$4.4 million average) of the distribution of matched executives. Taxable income at the $95^{\text {th }}$ percentile of the matched sample ( $\$ 7.8$ million average) is, on average, over 60 percent larger than that at the $99.99^{\text {th }}$ percentile of the overall distribution. At the $99^{\text {th }}$ percentile (average $\$ 21.4$ million) of the matched distribution, average taxable income is roughly 350 percent larger than that at the $99.99^{\text {th }}$ percentile of the overall distribution. Thus, our matched sample is, in general, not only characterized by high incomes, but by extraordinarily high incomes. That is, 30 percent of our matched sample is composed of incomes that are higher than 999 out of 1,000 taxpayers - with a sizable portion of our distribution not having a close comparison group in the work of Piketty and Saez (2003), who do not present incomes for percentiles beyond the $99.99^{\text {th }}$.

\footnotetext{
${ }^{19}$ All real measures are in 2000 dollars (as adjusted by the CPI-U), unless otherwise stated.
} 
Figure 3

Taxable Income for Executives and All Taxpayers

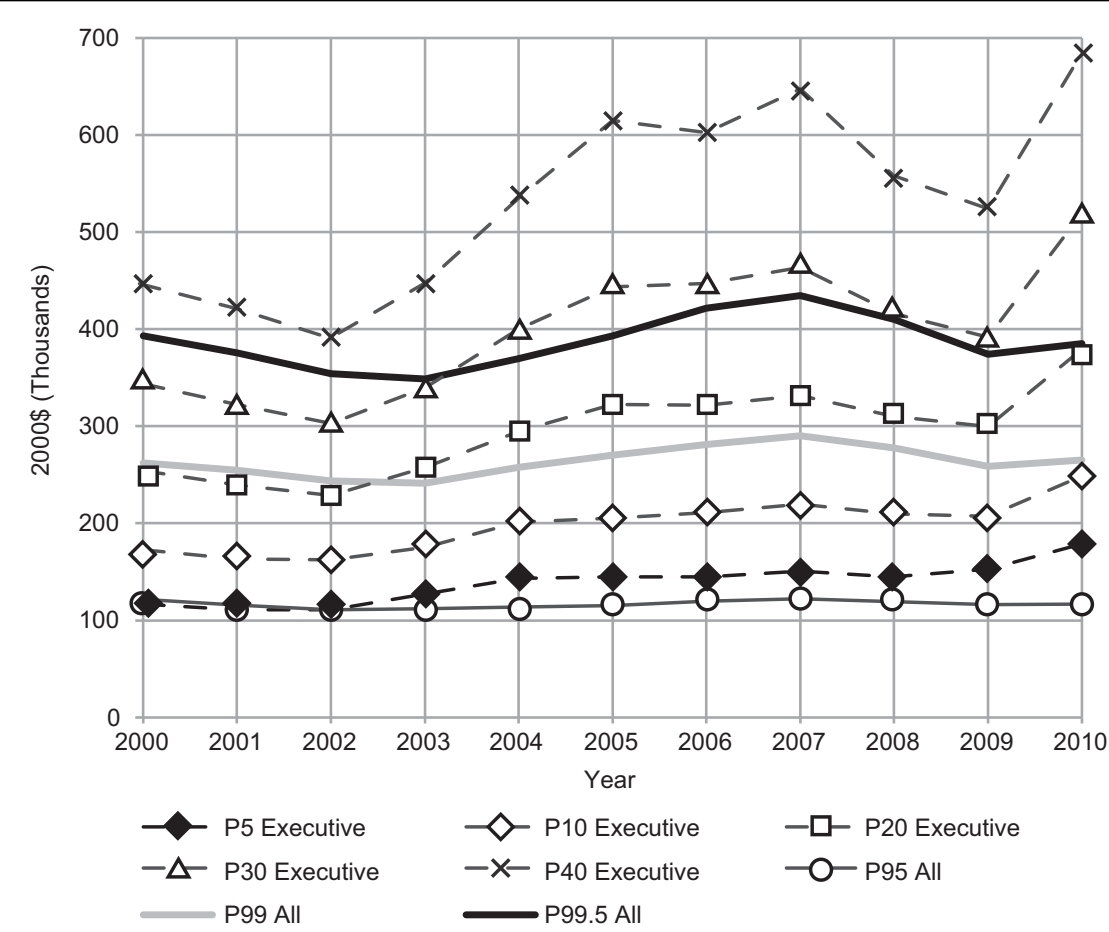

Notes: Dotted lines represent taxable income at points in the distribution of the Execucomp Sample. Solid lines represent taxable income at points in the overall income distribution (as tabulated by Piketty and Saez (2003)).

Source: Authors' calculations from IRS tax return data and tabulations from IRS data by Piketty and Saez (2003)

\section{Trends Since 2000}

The first decade of the $21^{\text {st }}$ century was an unusual period. The decade began with a minor recession in the aftermath of the bursting of the tech bubble. The housing and financial sectors fueled economic growth through 2006, after which the economy stalled and then was hit by the financial crisis and Great Recession, from which it has yet to fully recover. As a result, 2010 pre-tax incomes for most percentiles in the top 10 percent (of the overall distribution) are about the same (in real terms) as they were 


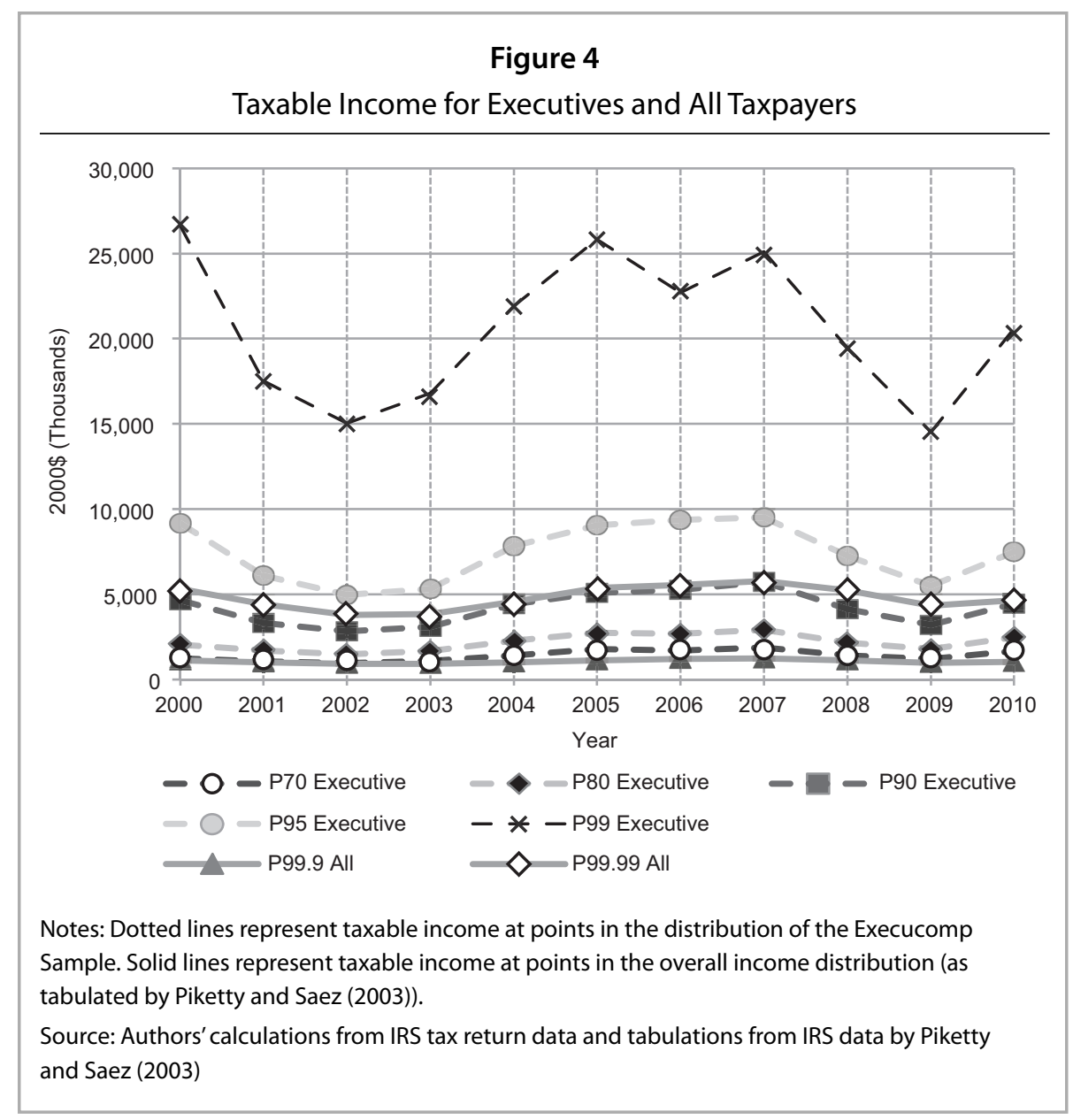

in 2000. The exception is individuals in the top half of one percent of the distribution, who experienced declines in real income. For example, incomes fell (i.e., real incomes, not income shares) by 2 percent for those at the $99.5^{\text {th }}$ percentile, by 7.4 percent for those at the $99.9^{\text {th }}$ percentile, and by 12.4 percent for those at the $99.99^{\text {th }}$ percentile. Despite declines for those at the right-tail of the distribution, trends over the past several decades suggest these top groups will more than make up for this decline as the economy strengthens.

Turning to our matched sample, Figures 3 and 4 suggest most executives experienced substantial increases in real taxable income (again excluding capital gains). In fact, from 
the $5^{\text {th }}$ to $60^{\text {th }}$ percentiles, we find income growth of between 34 and 43 percent over this period. Figure 3 suggests executives fared better over this period than did similarly situated taxpayers, who in general experienced no net income growth (as tabulated by Piketty and Saez, 2003). ${ }^{20}$

It is not until the $90^{\text {th }}$ percentile of our matched sample that incomes fall in real terms. Average taxable income (excluding capital gains) at the $90^{\text {th }}$ percentile of our matched sample is over $\$ 4.4$ million on average, which roughly corresponds to the $99.99^{\text {th }}$ percentile of the overall distribution income distribution. In this case the pattern for executives and similarly situated taxpayers is nearly identical. Real taxable income for executives at the $90^{\text {th }}$ percentile of our matched sample fell from 2000 to 2010 by close to 11 percent, as compared to a decline of about 12.5 percent for the $99.99^{\text {th }}$ percentile for all tax returns. Moving up the distribution, the drop in taxable income for executives is much larger - and average incomes are so high that no comparable income group exists in Piketty and Saez's (2003) tabulations. At the $95^{\text {th }}$ percentile ( $\$ 7.8$ million average taxable income) of our matched sample, taxable income fell by close to one quarter from 2000 to 2010 . At the $99^{\text {th }}$ percentile ( $\$ 21.4$ million average taxable income), the decline was over 28 percent.

The coefficient of variation normalizes these data to focus on variation (as measured by the standard deviation) as a share of mean income for each of the percentiles (Table 3). For both the IRS and Execucomp income measures, volatility increases for higher percentiles of the income distribution. The increase in volatility is much greater for the Execucomp measure, where the coefficient of variation ranges from 0.09 for the $5^{\text {th }}$ percentile to 0.27 for the $99^{\text {th }}$ percentile. For taxable income, this measure ranges from 0.14 for the $5^{\text {th }}$ percentile and peaks at 0.22 for the $95^{\text {th }}$ percentile.

\section{Table 3}

The Coefficient of Variation for Various Points in the Income Distribution

\begin{tabular}{lccccccccccc}
\hline & $\mathrm{P} 5$ & $\mathrm{P} 10$ & $\mathrm{P} 20$ & $\mathrm{P} 30$ & $\mathrm{P} 40$ & $\mathrm{P} 50$ & $\mathrm{P} 60$ & $\mathrm{P} 70$ & P80 & P90 & P95 \\
\hline $\begin{array}{l}\text { Taxable income } \\
\begin{array}{l}\text { Executive } \\
\text { compensation }\end{array}\end{array}$ & 0.141 & 0.129 & 0.148 & 0.159 & 0.174 & 0.188 & 0.200 & 0.214 & 0.213 & 0.221 & 0.223 \\
\hline
\end{tabular}

Source: Authors' calculations based on IRS and Execucomp data

\footnotetext{
${ }^{20}$ As noted in Section II, this analysis is of repeated cross-sections and thus does not follow the same cohort over time.
} 


\section{E. Income Trends by Industry}

Figure 5 reports trends in mean gross income for Execucomp executives in selected industries for 2000 to 2010. Industry codes are from the Execucomp data, while the gross income measure (net of capital gains) is from the tax data. Gross income is constructed in a manner analogous to Bakija, Cole, and Heim (2010) and is composed of total income (as reported on the Form 1040) less taxable Social Security benefits, unemployment compensation, state tax refunds, the deduction for self-employment taxes, and longterm capital gains. Not surprisingly, incomes fluctuate substantially with the business

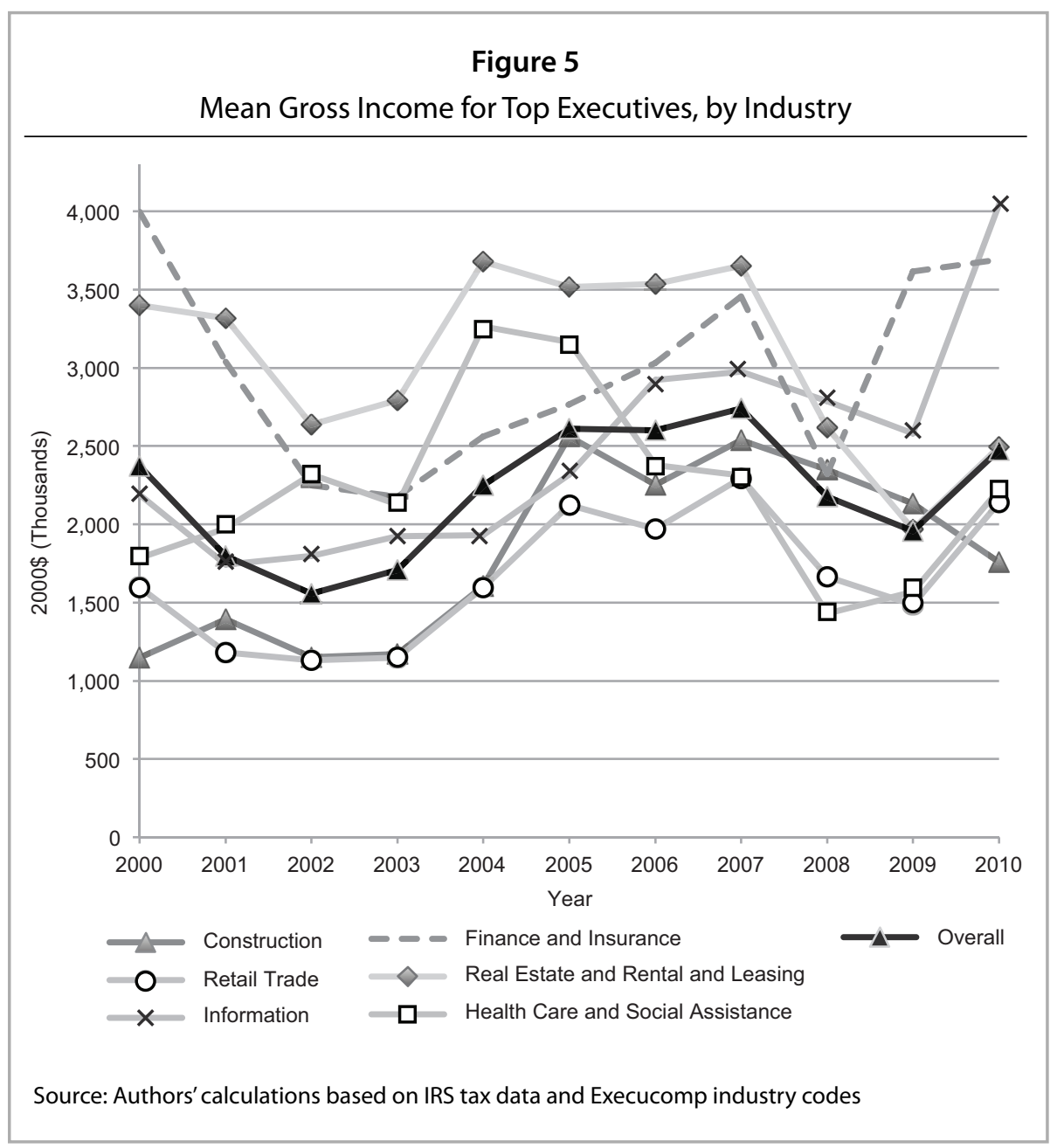


cycle and both levels and trends vary by industry. However, somewhat surprisingly, real mean incomes for many industries were higher in 2010 than in 2000; in fact, this is true for our matched sample overall.

One might suspect that executives in finance would have suffered disproportionately during the Great Recession. This certainly was the case in 2008: top executives in finance and insurance reported incomes that were 33 percent lower than in 2007 on average. However, by 2009, incomes for this group were above their 2007 level. In fact, Figure 5 suggests the period from 2000 to 2003 was actually worse for this group: mean gross income (at least through 2010) has not returned to its peak in 2000.

Top executives in real estate, also at the center of the financial crisis, suffered bigger losses than those in finance. From 2000 to 2006, mean annual gross income for executives in real estate was 35 to 85 percent higher (depending on the year) than annual averages for the full matched sample. In 2009 and 2010, income for this sector was about equal to the overall mean. ${ }^{21}$

Recall that Kaplan and Rauh (2010) compare top executives in the financial and nonfinancial sectors for the years 1994 and 2004 using Execucomp income measures, as opposed to those from tax returns. Based on the trends in Figure 5, it appears that the pair of years chosen for this type of analysis can have a big impact on the results. For example, in two of the 11 years in our sample, gross income for executives in finance is just 6 percent or 7 percent above the mean for our full matched sample. However, in three of the years, executives in finance report incomes 69 percent to 85 percent higher than the overall average.

\section{F. Income Growth over Selected Years}

Tables 4, 5, and 6 report income growth over pairs of years for executives in a number of industries. The tables are broken down by segments of the top one percent of the overall income distribution, as reported by Piketty and Saez (2003). As in Figure 5, these tables assign executives to industries based on Execucomp data, while using income variables reported to the IRS. These tables are analogous to Tables 8 to 10 from Bakija, Cole, and Heim (2010), focusing on various segments of the top 1 percent of the income distribution. Note that Bakija, Cole, and Heim focus on average growth rates for periods between 1979 and 2005 for various occupations. By contrast, we compare growth rates over pairs of years between 2000 and 2010 and compare executives in different industries. The occupation categories used by Bakija, Cole, and Heim are very broad, and in many cases are more akin to industry classifications. Their data end in 2005, several years before the financial crisis and Great Recession.

\footnotetext{
${ }^{21}$ Top executives in mining (not depicted in Figure 5) saw their incomes skyrocket through 2008, as incomes in many other industries dropped. This may have been driven by increases in energy prices and the discovery and development of new shale oil and natural gas reserves.
} 


\section{Table 4}

Income Growth by Industry over Selected Years: Executives in the 99-99.5th Percentiles of the Overall Income Distribution

\begin{tabular}{lcccc}
\hline NAICS & $2000-2002$ & $2002-2006$ & $2006-2009$ & $2009-2010$ \\
\hline Non-finance & -9.2 & 18.5 & -10.2 & 3.0 \\
Finance and insurance & -10.1 & 18.7 & -10.4 & 4.1 \\
Mining, quarrying, and oil and & -7.3 & 11.8 & -9.4 & 1.5 \\
$\quad$ gas extraction & -9.3 & 20.6 & -9.8 & 4.1 \\
Utilities & -8.9 & 18.5 & -10.2 & 3.2 \\
Manufacturing & -11.9 & 23.7 & -12.7 & 6.1 \\
Wholesale trade & -7.2 & 19.5 & -12.9 & 4.2 \\
Retail trade & -12.9 & 19.6 & -7.0 & \\
Transportation and warehousing & -10.6 & 17.7 & -9.5 & 1.2 \\
Information & -12.7 & 21.5 & -9.7 & 0.4 \\
Real estate and rental and & & & & \\
$\quad$ leasing & -10.0 & 18.8 & -10.9 & 1.5 \\
Professional, scientific, and & & & & \\
$\quad$ technical services & -13.6 & 15.8 & -7.6 & 7.3 \\
Health care and social assistance & -2.1 & 11.0 & -8.6 & 6.5 \\
Accommodation and food services & -9.3 & 18.4 & -10.2 & 3.2 \\
\hline Overall &
\end{tabular}

Source: Authors' calculations based on income from the CDW, industry codes from the Execucomp and income cutoffs from Piketty and Saez (2003)

Table 4 reports growth rates by industry for executives falling between the $99^{\text {th }}$ and $99.5^{\text {th }}$ percentile - i.e., the bottom half of the top one percent - of the overall income distribution. For this part of the income distribution, growth rates vary greatly across years; however, variation across industries is fairly modest. In particular, patterns exhibited by both the financial and non-financial sectors (which receive much attention in Kaplan and Rauh (2010)) are similar to those of the overall sample. For the overall matched sample, income dropped by over 9.2 percent from 2000 to 2002, climbed by 18.4 percent from 2002 to 2006, and fell by 10.2 percent from 2006 to 2009. By comparison, Bakija, Cole, and Heim report that this group's income increased at an annual average real rate of 0.6 percent between 1979 and 2005 . While a simple linear trend connecting our 2000 and 2010 measures has a slope of about zero, this masks large income swings over the decade. 


\section{Table 5}

Income Growth by Industry over Selected Years:

Executives in the 99.5th-99.9th Percentiles of the Overall Income Distribution

\begin{tabular}{lcccc}
\hline NAICS & $2000-2002$ & $2002-2006$ & $2006-2009$ & $2009-2010$ \\
\hline Mining, quarrying, and oil and & -10.4 & 32.6 & -16.7 & 2.7 \\
$\quad$ gas extraction & -14.2 & 30.0 & -15.4 & 7.9 \\
Utilities & -15.7 & 22.0 & -20.5 & 9.2 \\
Construction & -14.2 & 27.8 & -15.8 & 6.0 \\
Manufacturing & -8.7 & 27.2 & -21.4 & 10.4 \\
Wholesale trade & -12.5 & 30.0 & -16.3 & 7.1 \\
Retail trade & -13.5 & 28.3 & -16.3 & 2.2 \\
Transportation and warehousing & -13.8 & 26.6 & -13.0 & 8.8 \\
Information & -13.9 & 24.3 & -14.5 & 6.2 \\
Finance and insurance & -14.2 & 31.1 & -17.1 & 1.6 \\
Real estate and rental and leasing & -10.5 & 25.0 & -15.3 & 5.3 \\
Professional, scientific, & & & & \\
$\quad$ and technical services & -10.2 & 39.7 & -15.6 & 4.1 \\
Health care and social assistance & -13.0 & 19.7 & -8.9 & 12.8 \\
Accommodation and food services & -13.5 & 27.9 & -15.4 & 6.4 \\
Non-finance & -13.5 & 27.6 & -15.3 & 6.3 \\
\hline Overall &
\end{tabular}

Source: Authors' calculations based on income from the CDW, industry codes from the Execucomp and income cutoffs from Piketty and Saez (2003)

Moving to Table 5 and those above the $99.5^{\text {th }}$ percentile but below the $99.9^{\text {th }}$ percentile, growth rates are more volatile, but the overall trend is a good approximation for most industries. Once again, the financial sector appears very similar to a composite of the non-financial sectors. Variation in income growth across years is amplified compared to the bottom half of the top 1 percent from Table 4. For the first three sets of paired years, average income growth (or decline) is 50 percent larger than in Table 4.

Table 6 reports measures for executives with incomes above the $99.9^{\text {th }}$ percentile of the overall income distribution. While average income in 2010 was roughly the same as that in 2000 for most of the top 1 percent, incomes for the top permille - i.e., the top tenth of the top 1 percent - were 13 percent lower at the end of this period. In other respects, the patterns in the top permille are quite different from others in the 


\section{Table 6}

Income Growth by Industry over Selected Years: Executives in the 99.9th-100th Percentiles of the Overall Income Distribution

\begin{tabular}{lcccc}
\hline NAICS & $2000-2002$ & $2002-2006$ & $2006-2009$ & $2009-2010$ \\
\hline $\begin{array}{l}\text { Mining, quarrying, and oil and } \\
\quad \text { gas extraction }\end{array}$ & -54.5 & 189.7 & -26.2 & 1.7 \\
Utilities & -18.3 & 59.3 & -12.5 & -23.4 \\
Construction & 9.3 & 78.5 & -46.2 & -2.4 \\
Manufacturing & -18.0 & 17.8 & -16.1 & 16.9 \\
Wholesale trade & -31.8 & 50.7 & -21.3 & 27.7 \\
Retail trade & -23.9 & 12.7 & 0.1 & -1.9 \\
Transportation and warehousing & -14.6 & 31.2 & -1.9 & 20.6 \\
Information & -37.6 & 18.3 & 14.0 & -9.1 \\
Finance and insurance & -30.5 & 51.7 & -42.6 & 18.9 \\
Real estate and rental and leasing & -50.4 & 38.4 & -21.9 & 2.6 \\
Professional, scientific, & -46.1 & 39.5 & -31.4 & 45.8 \\
$\quad$ and technical services & & & & \\
Health care and social assistance & -5.3 & 27.5 & -45.6 & 28.8 \\
Accommodation and food services & -21.8 & 68.3 & -25.8 & 11.7 \\
Non-finance & -38.4 & 58.0 & -22.7 & 18.5 \\
\hline Overall & -36.1 & 55.0 & -26.3 & 19.1 \\
\hline
\end{tabular}

Source: Authors' calculations based on income from the CDW, industry codes from the Execucomp, and income cutoffs from Piketty and Saez (2003)

top 1 percent. Variation across industries and growth rates across paired years are greatly exaggerated compared to other segments of the top 1 percent. The early part of the decade was especially volatile for individuals in this group, who experienced an income drop from 2000 to 2002 that was 170 percent greater than the decline for those between the $99.5^{\text {th }}$ and $99.9^{\text {th }}$ percentiles. The post-tech bubble recovery compensated for these losses, as the highest permille's income growth was 55 percent from 2002 to 2006, or twice that of those in the next four permilles. As with the bursting of the tech bubble, the impact of the Great Recession was greater for the top permille than for the next four permilles, as average incomes for the former group dropped by 26.3 percent from 2006 to 2009 , or 70 percent more than the decline in average incomes for the latter group. While all segments of the top 1 percent experienced income gains from 2009 to 2010, the top permille reported enormous gains of 19.1 percent. 


\section{CONCLUSION}

The years 2000 to 2010 were a tumultuous period for top executive incomes, as was the case for the broader economy. What are now classified as stock awards have grown greatly in importance over this period, and are arguably the largest source executive compensation. Stock options are the key source of volatility in executive incomes. In "good" years, these options may represent more than one-third of compensation for top executives. Despite steep drops in executive compensation in the early 2000s and during the Great Recession, executive pay for this group has more than doubled in real terms since 1992.

Not all top executives have extraordinarily high incomes. However, the vast majority are concentrated at the very top of the income distribution: 95 percent of top executives are in the top 5 percent of the income distribution and 30 percent are in the top 0.1 percent of the overall income distribution.

Executive incomes, mirroring trends in the broader income distribution, are most volatile at the right tail of the distribution. In general, trends for top executives in finance and non-finance industries were quite similar from 2000 to 2010. This is consistent with findings from Kaplan and Rauh (2010) for an earlier period. Patterns for those above the $99.9^{\text {th }}$ percentile of the income distribution are quite different from other segments of the top 1 percent. In general, income swings were amplified for this group and showed greater heterogeneity across industries. At this percentile, the finance sector was an outlier as the income decline from 2006 to 2009 in that sector was much more pronounced than that experienced by executives in non-finance sectors.

\section{ACKNOWLEDGEMENTS}

The authors would like to thank William Gentry and Mark Borges for helpful comments.

\section{DISCLAIMERS}

This research is part of work undertaken for the staff of the Joint Committee on Taxation, but as members of both parties and both houses of Congress comprise the Joint Committee on Taxation, this work should not be construed to represent the position of any member of the Committee.

\section{REFERENCES}

Atkinson, Anthony B., and Thomas Piketty (eds.), 2007. Top Incomes over the Twentieth Century: A Contrast between Continental European and English Speaking Countries. Oxford University Press, Oxford, UK.

Auten, Gerald, and Geoffrey Gee, 2009. "Income Mobility in the United States: New Evidence from Income Tax Data." National Tax Journal 62 (2), 301-328. 
Bakija, Jon, Adam Cole, and Bradley T. Heim, 2010. "Jobs and Income Growth of Top Earners and the Causes of Changing Income Inequality: Evidence from U.S. Tax Return Data.” Department of Economics Working Paper 2010-24. Williams College, Williamstown, MA.

Bank, Steven A., Kirk J. Stark, and Joseph J. Thorndike, 2008. War and Taxes. Urban Institute Press, Washington, DC.

Bebchuk, Lucian, Jesse M. Fried, and David I. Walker, 2002. "Managerial Power and Rent Extraction in the Design of Executive Compensation." University of Chicago Law Review 69 (3), 751-846.

Bickley, James M., 2012. “Employee Stock Options: Tax Treatment and Tax Issues.” CRS Report RL31458. Congressional Research Service, Washington, DC.

Bivens, Josh, and Lawrence Mishel, 2013. "The Pay of Corporate Executives and Financial Professionals as Evidence of Rents in Top 1 Percent Income.” Journal of Economic Perspectives 27 (3), 57-78.

Borges, Mark, 2012. SEC Executive Compensation Disclosure Rules, $2^{\text {nd }}$ Edition. American Bar Association, Chicago, IL.

Burkhauser, Richard V., Jeff Larrimore, and Kosali Simon, 2012. "A Second Opinion on the Economic Health of the American Middle Class," National Tax Journal 65 (1), 7-32.

Burkhauser, Richard V., Shuaizhang Feng, Stephen P. Jenkins, and Jeff Larrimore, 2012. "Recent Trends in Top Income Shares in the United States: Reconciling Estimates from March CPS and IRS Tax Return Data.” Review of Economics and Statistics 94 (2), 371-388.

Carroll, Robert, and David Joulfaian, 1997. "Taxes and Corporate Choice of Organizational Form." Office of Tax Analysis Working Paper 73. The U.S. Department of the Treasury, Washington, DC.

Corak, Miles, 2013. "Income Inequality, Equality of Opportunity, and Intergenerational Mobility." Journal of Economic Perspectives 27 (3), 79-102.

Dahl, Molly, Thomas DeLeire, and Jonathan A. Schwabish, 2008. "Recent Trends in the Variability of Individual Earnings and Household Income.” Congressional Budget Office, Washington, DC.

Eissa, Nada O., and Seth H. Giertz, 2006. "Trends in High Income and Behavioral Responses to Taxation: Evidence from Executive Compensation and Statistics of Income Data." CBO Working Paper 2006-14. Congressional Budget Office, Washington, DC.

Frydman, Carola, and Dirk Jenter, 2010. "CEO Compensation.” Annual Review of Financial Economics 2 (1), 75-102.

Frydman, Carola, and Raven E. Saks, 2010. "Executive Compensation: A New View from a Long-Term Perspective, 1936-2005.” Review of Financial Studies 23 (5), 2099-2138.

Gabaix, Xavier, and Augustin Landier, 2008. “Why Has CEO Pay Increased So Much?” Quarterly Journal of Economics 123 (1), 49-100.

Gabaix, Xavier, Augustin Landier, and Julien Sauvagnat, 2013. "CEO Pay and Firm Size: An Update after the Crisis.” NBER Working Paper No. 19078. National Bureau of Economic Research, Cambridge, MA. 
Goolsbee, Austan, 2000. "What Happens When You Tax the Rich? Evidence from Executive Compensation.” Journal of Political Economy 108 (2), 352-378.

Hall, Brian, and Jeffrey Liebman, 1998. “Are CEOs Really Paid Like Bureaucrats?” Quarterly Journal of Economics 113 (3), 653-691.

Hall, Brian, and Jeffrey Liebman, 2000. "The Taxation of Executive Compensation.” In Poterba, James M. (ed.), Tax Policy and the Economy, Volume 14, 1-44. MIT Press, Cambridge, MA.

Hall, Brian and Kevin J. Murphy, 2003, “The Trouble with Stock Options.” Journal of Economic Perspectives, 17 (3), 49-70.

Kahneman, Daniel, 2011. Thinking Fast and Slow. Farrar, Straus and Giroux, New York, NY.

Kaplan, Steven N., and Joshua Rauh, 2010. "Wall Street and Main Street: What Contributes to the Rise in the Highest Incomes?” Review of Financial Studies 23 (3), 1004-1050.

Kaplan, Steven N., and Joshua Rauh, 2013. "It's the Market: The Broad-Based Rise in the Return to Top Talent.” Journal of Economic Perspectives 27 (3), 35-56.

Kopczuk, Wojciech, Emmanuel Saez, and Jae Song, 2010. "Earnings Inequality and Mobility in the United States: Evidence from Social Security Data Since 1937." Quarterly Journal of Economics 125 (1), 91-128.

Kuhnen, Camelia, and Jeffrey Zwiebel, 2009. "Executive Pay, Hidden Compensation and Managerial Entrenchment.” Working Paper. Kellogg School of Management, Evanston, IL.

Mankiw, N. Gregory, 2013. "Defending the One Percent." Journal of Economic Perspectives 27 (3), 21-34.

Meyer, Bruce, and James X. Sullivan, 2012. "Identifying the Disadvantaged: Official Poverty, Consumption Poverty, and the New Supplemental Poverty Measure." Journal of Economic Perspectives 26 (3), 111-136.

Piketty, Thomas, and Emmanuel Saez, 2003. "Income Inequality in the United States, 1913-1998.” Quarterly Journal of Economics 118 (1), 1-39.

Saez, Emmanuel, 2013, "Striking it Richer: The Evolution of Top Incomes in the United States (Updated with 2011 Estimates).” Working Paper. University of California, Berkeley, CA.

Saez, Emmanuel, Joel Slemrod, and Seth H. Giertz, 2012. "The Elasticity of Taxable Income with Respect to Marginal Tax Rates: A Critical Review.” Journal of Economic Literature 50 (1), 3-50.

Slemrod, Joel, 1996. "High-Income Families and the Tax Changes of the 1980s: The Anatomy of Behavioral Response.” In Feldstein, Martin, and James M. Poterba (eds.), Empirical Foundations of Household Taxation, 169-89. University of Chicago Press, Chicago, IL.

Stern, Gary H., and Ron J. Feldman, 2004. Too Big to Fail: The Hazards of Bank Bailouts. Brookings Institution Press, Washington, DC. 


\section{APPENDIX A: MATCHING SUMMARY}

The CDW and Execucomp do not use the same numeric individual identifiers. For example, the CDW includes Taxpayer Identification Numbers (TINs), while the Execucomp includes an executive identification number (EXECID). Matches can be made based on names and Employer Identification Numbers (EINs). However, matching on strings is complicated, as names are not unique and some individuals may use nicknames on one form and formal names another. With over 125 million tax returns available per year, matching can be complicated and time-consuming. We initially select individuals with at least one Form W-2 with Box 1 (earned) income exceeding \$99,000 in a given year. Our sample is then comprised of all the Form W-2s associated with that individual for that year. These W-2 data - which contain between 5 million and 8 million observations per year - include EINs and individuals' names. They are available for tax years 2000 through 2011.

\section{A1. Match Strategy 1}

We use two separate, but similar, matching strategies. Both involve creating annual (i.e., yearspecific) Execucomp extracts to match with annual (i.e., year-specific) CDW samples. The first strategy matches executives to CDW data based on the last name and first initial of an individual for a given year. Any match (i.e., an EXECID-TIN match) with a conflicting year of birth, gender, or middle initial is dropped. We further filter these matches in three successive waves.

Any "matched observations" where the first name, middle initial, gender, and EIN match are placed in the first bin. All of the executives found in the first bin are then stripped out of the Execucomp sample, and the same match is performed (by last name and first initial, with the "conflict" filters) on the remaining Execucomp data. These matches - which are placed in the second bin — are subject to slightly different criteria: the EINs are not required to match, but the first name, middle initial, gender, and year of birth are required to match.

After removing the executives found in the first two bins from the Execucomp data, the third bin of matches is identified using the same match on the remaining Execucomp data. The criteria for the third bin are weaker than the first two: the first name and middle initial of the individual must match.

All of the matches at each of the three stages are tested for between-year and within-year variation in the EXECID-TIN matches. For example, if an executive has three matched TINs in the same year, those three TINs must be the same. Similarly, if an executive has matched TINs in multiple years, all of the TINs must be the same. If either of these criteria does not hold all of the "matches" for that executive are dropped.

As expected, the amount of within-year and between-year TIN-EXECID conflicts increase with each successive bin (i.e., more matches are dropped). Similarly, the matches found in each successive wave decrease dramatically.

\section{A2. Match Strategy 2}

The second strategy matches year-specific Execucomp extracts with year-specific CDW tax data by EIN, last name, and first initial. Matches with conflicting middle names, genders, or years of birth are dropped (as in Strategy 1). The matches are then subject to the criterion that either the first names must match or the middle initials must match.

As before, EXECID matches with conflicting TINs within a year or between years are dropped. In this case, very few observations are dropped. Finally, executives who are matched with the same TIN as another executive are dropped. This happens in a small number of cases where executives do not have unique Execucomp identifiers. 